\title{
Flowers and Insects in Great Britain.
}

\author{
PART III. \\ Observations on the most Specialized Flowers \\ of the Clova Mountains.
}

BY

J. C. WILLIS, M.A.,

Director of the Royal Botanic Gardens, Ceylon.

AND

I. H. BURKILL, M.A.,

Assistant Reporter on Economic Products to the Government of India.

WE now publish our observations on the fertilization, about Clova in the Eastern Grampians, of the flowers specially adapted for the visits of bees and butterflies ${ }^{1}$. The next part of our paper will complete the series, and will terminate with a general review.

Class F $\S$ it. Suited for Diurnal Lepidoptera.

91. Silene acaulis, Linn. [Lit. Brit., Wilson 2567 ; Arct. 7, 34, 36, 38; Aurivillius 78; Axell 81;Alps 2, 9, 21 b, 34; Ricca 2071 ; Pyren. 17.] A marked Lepidoptera-flower at Clova as in the Alps and Pyrenees, Bombi having only been recorded as visiting it in Arctic regions. The flowers are polygamo-trioecious, the hermaphrodite condition being common, and fruit ripening very abundantly. The perfect flowers are proterandrous. The larger flowers have a breadth

1 Pt. I (Lowland flowers), Ann. of Bot. I 895, p. 227 ; II (Clova), do. 1903, p. 3 I 3.

[Annals of Botany, Vol. XVII. No. LXVII. June, 1903.] 
of $\mathrm{I}$ o $\mathrm{mm}$. and a depth of $8 \mathrm{~mm}$. Two points call for mention: (I) the apparently greater separation of the sexes on the continent, and (2) the more accessible honey in a form of the species found in Greenland.

Visitors. Lepidoptera. Heterocera: Geometridae: (I) Thera variata Schiff., 8. VII. 94, 4. VII. 95, 22. VI. 96, 23-2,700 ft. (2) Larentia salicata Hb., 8. VII. 94, 2,400 ft. Pyralidae: (3) Scopula alpinalis Schiff., sh. 4. VII. 95, 26-2,700 ft. Hymenoptera. Aculeata: Apidae: (4) Bombus jonellus Kirby, sh. 22. VI. 96, 2,300 ft. Diptera. Empidae: (5) Empis tessellata F., sh. 22. VI. 96, 2,300 ft. Chironomidae: (6) Chironomus sp., ?sh. 6-I3. VII. 95, 2,000 ft. Coleoptera. (7) Anthophagus alpinus Payk., sh. 4. VII. 96, 22. VI. 96, $25^{-2,700 ~ f t . ~(8) ~ M e l i g e t h e s ~ s p ., ~ s h . ~ I ~ 5 . ~ V I . ~}$ 99, I,900 ft. Thysanoptera. (9) Thrips sp., sh. 4. VII. 95, $2,700 \mathrm{ft}$.

92. Habenaria conopsea, Reichb. [Lit. Brit. 23 ; Darwin 483 ; N.C.E. 1, 4, 16, 44; Arct. 36 ; Alps 2, 9, 21 b.] A Lepidoptera-flower known to be fertilized by moths and butterflies in North Norway, Scotland, England, and the Alps. Some differences in the length of the spur are to be noted; it is recorded as IO-II mm. long in North Norway, $15 \mathrm{~mm}$. in South Sweden, I3-I4 mm. in the Alps, and is IO-I $2 \mathrm{~mm}$. long at Clova. We have watched flowers at night without observing insects to visit them.

Visitors. Lepidoptera. Rhopalocera: (I) Argynnis aglaia L., sh. 2 5. VI. 95, $900 \mathrm{ft}$. once. (2) Lycaena icarus Rott., sh. I. VII. 95, $900 \mathrm{ft}$. once. Heterocera: Crambidae: (3) Crambus sp., sh. 2. VII. 95, $900 \mathrm{ft}$. Eriocephalidae: (4) Eriocephala calthella L., 8. VI.-2. VII. 95, 8-900 ft. Diptera. Tachinidae: (5) Siphona geniculata Deg., 2 2. VI. 95, $800 \mathrm{ft}$. once. Anthomyiidae: (6) Anthomyia sp., 2. VII. $95,900 \mathrm{ft}$., 26 . VI. $96, \mathrm{I}, 100 \mathrm{ft}$.

Class F $\S$ i2. Suited for Nocturnal Lepidoptera.

93. Lonicera Periclymenum, Linn. [Lit. Brit. 23, 39; N.C.E. 1, 3 c, 8, 11, 14, 14 a, 18, 31, 33 ; Knuth 1234; Warnstorf 2508; Alps 9.] A moth-flower but somewhat visited by bumble-bees. Apis was seen to lick the stigma. 
Visitors. Lepidoptera. Heterocera: Noctuidae: (I) Plusia pulchrina Haw., sh. 22. VI. 95. Hymenoptera. Aculeata: Apidae: (2) Apis mellifica L., cp. and seeking h. 20-22. VI. 95. (3) Bombus hortorum L., sh. 22. VI. 96, I8. VI. 99. Diptera. Empidae: (4) Empis punctata Mg., seeking h. 2 I. VI. 96. Anthomyizdae: (5) Trichophthicus sp., fp. 20-23?. VI. 95. All at $800 \mathrm{ft}$.

\section{Class H $\S$ I3. Lychnis Type.}

94. Lychnis diurna, Sibth. [Lit. Brit. 23, 39 ; White 2548 ; N.C.E. 1, 11, 21 a, 34; De Vries 2460; Arct. 36 ; Alps 2, 9, 16.] This flower is little visited at Clova, where the tube is IO-I $5 \mathrm{~mm}$. long. In the Alps many butterflies seem to go to it.

Visitors. Diptera. Syrphidae: (I) Platychirus manicatus Mg., ? fp. 15. VI. 99, $900 \mathrm{ft}$. (2) Rhingia campestris Mg., sh. ${ }_{25}$. VI. 95, $800 \mathrm{ft}$. Coleoptera. (3) Meligethes viridescens F., sh. and fp. 25 . VI. -4 . VII. 95 , I 5. VI. $99,8-900 \mathrm{ft}$.

95. Lychnis fios-cuculi, Linn. [Lit. Brit. 23 ; N.C.E. 1, 3 b, 14, 16, 18, 21 a, 21 b, 25, 34; De Vries 2460;Alps 9.] A bee and Lepidoptera-flower, with (at Clova) a tube $7-9 \mathrm{~mm}$. long.

Visitors. Lepidoptera. Rhopalocera: (I) Lycaena icarus Rott., sh. 26. VI. 95, $800 \mathrm{ft}$. Hymenoptera. Aculeata: Apidae: (2) Bombus lapponicus F., seeking h. 26 . VI. $95,800 \mathrm{ft}$. (3) B. agrorum F., sh. 2 I. IX. 95, 900 ft. Diptera. Syrphidae: (4) Rhingia campestris Mg., sh. 26. VI.-I. VII. 95, $800 \mathrm{ft}$. (5) Platychirus manicatus Mg., seeking h. and fp. 23. VI.-4. VII. 95, 800 ft. Empidae: (6) Empis tessellata F., sh. r. VII. 95, $800 \mathrm{ft}$. Anthomyiidae: (7) r sp., 23. VI. $95,800 \mathrm{ft}$.

96. Lychnis alpina, Linn. [Lit. Brit. 26 ; Arct. 36, 38 ; Axell 81; Alps 9, 34; Kirchner 1185.] The following account is drawn up from Clova specimens. The flower is strongly proterandrous. After the dehiscence of the anthers, the stamens bend outwards ; then the styles elongate and separate, bending so as eventually to be at right angles to the ovary across the mouth of the flower. Ultimate autogamy is possible by 
means of anthers still adhering to their filaments, and seems to take place, fruiting being regular. The flowers are I2I $4 \mathrm{~mm}$. in diameter; the petals have a claw $3 \mathrm{~mm}$. long and a limb $4 \mathrm{~mm}$. notched to halfway. As the internode between sepals and petals is about I $\mathrm{mm}$. long, the honey at the base of the flower is about $4 \mathrm{~mm}$. removed from the mouth, a distance a little less than the width of the mouth. Thus the tube is rather funnel-shaped than tubular. The flowers are very variable in the number of parts, six petals being frequently, seven occasionally, present. It is possible that the flower should be regarded as belonging to Class $\mathrm{B}$.

Visitors. Hymenoptera. Aculeata: Apidae: (I) Psithyrus quadricolor Lep., sh. 2. VII. 96, once. Diptera. Chironomidae: (2) I sp., 2. VII. 96. Anthomyiüdae: (3) Trichophthicus sp., sh. 27. VI.-2. VII. 96. Thysanoptera. (4) Thrips sp., 2. VII. 96. All at 2,850 ft.

97. Primula vulgaris, Huds. [Lit. Brit. 23, 29; Christy in Trans. Essex Field Club, iii. p. I95; Darwin 470 and 485 ; Briggs 290 ; Scott 2253 ; N.C.E. 1, 33.] One of us gave some account of the fertilization of the Primrose (see lit. 29) a few years ago, showing how the conditions of its fertilization are hardly known. Since then we have noticed that it is very abundantly visited at Kew by a bee, Anthophora acervorum, and is visited also by it in Essex (see Miller Christy, loc. cit.). This insect does not occur at Clova. We have seen few visitors in our district. The tube is $\mathrm{I} 2.5^{-1} 6 \mathrm{~mm}$. long there ; it is longer in England and Germany. We found certain long-styled flowers with the style dwarfed, probably in deformity, and in them the Anthomyiids were able to push their way down the throat to the stamens.

Visitors. Hymenoptera. Aculeata: Apidae: (1) Bombus hortorum L., sh. 20. V. $97,800 \mathrm{ft}$. once. Diptera. Anthomyizdae: (2) Anthomyia sulciventris $\mathrm{Ztt}$., fp. and seeking h. 20-22. V. 97, 6-1,200 ft. freq. (3) Hylemyia sp., fp. 20. V. 97, 900 ft. Coleoptera. (4) Meligethes sp., fp. 22. V. 97 , 10. VI. 99, 700 ft. Araneida. (5) Xysticus sp., lying in wait on the corolla, 22. V. 97, $600 \mathrm{ft}$. 


\section{Class H $\$$ I4. Crocus Type.}

98. Crocus aureus, Linn. [Lit. Brit. 29.] In cultivation.

Visitors. Hymenoptera. Aculeata: Apidae: (I) Apis mellifica L., sh. and cp. 2-I 5. IV. 95, very ab. Diptera. Muscidae: (2) Pollenia rudis $F$., fp. 2. IV. 95, freq. (3) Lucilia cornicina F., fp. 2. IV. 95, freq. All at $800 \mathrm{ft}$.

\section{Class H $\S_{15}$. Viola Type.}

99. Viola palustris, Linn. [Lit. Brit. 23; N.C.E. 14.] Reproduction is largely by runners. The flowers are insignificant, with a spur only $2 \mathrm{~mm}$. long and with little honey. The stigma projects beyond the stamens. They are neglected by insects, so that we have only seen three individuals on them; the fourth (B. lapponicus) was observed on the flowers by the father of one of us, Mr. I. H. Burkill, sen. Knuth observed no visitors in the North Friesian Islands.

Visitors. Hymenoptera. Aculeata: Apidae: (I) Bombus lapponicus F., sh. 19. V. 98, I,400 ft. once. Diptera. Empidae: (2) Empis lucida Ztt., sh. I2. VI. 99, I7-2,500 ft. Anthomyizdae: (3) I sp., I8. V. $98,800 \mathrm{ft}$.

Ioo. Viola canina, Linn., and V. sylvatica, Fries. [Lit. Brit. 23, 29 ; Bennett 219; N.C.E. 1, 3 b, 14, 18, 25, 33, 40 ; MacLeod 1471 ; Alps 2.] Pronounced bee-flowers, but not well visited at Clova. The spur of V. sylvatica sometimes attains the length of $8 \mathrm{~mm}$., that of V. canina (segregate) is about $5 \mathrm{~mm}$. long. Once in the first-named it was found bitten through. The butterflies abroad in spring visit the flowers on the continent as at Clova; Bombi are recorded as visitors in Dumfriesshire and Yorkshire. The chasmogamic flowers seem to set little seed (cf. Linton in Bot. Exchange Club Rep. 1890, p. 284). Cleistogamic flowers follow them.

Visitors. Lepidoptera. Rhopalocera: (I) Pieris napi L., sh. 2 I. V. 96, 23. V. 97, I5. VI. 99, 6-I,000 ft. (2) Argynnis selene Schiff., sh. I5-I6. VI. 99, $900 \mathrm{ft}$. Hymenoptera. Aculeata: Apidae: (3) 
Bombus agrorum F., sh. 22. V. 97, $600 \mathrm{ft}$. Diptera. Tachinidae: (4) Siphona geniculata Deg., 21. V. 96, $800 \mathrm{ft}$. Anthomyiidae: (5) Anthomyia sulciventris Ztt., fp. 20-27. V. 97, 7-800 ft. Araneida. (6) Xysticus sp., lying in wait inside a flower, 2 I. V. 97, $800 \mathrm{ft}$.

IoI. Viola tricolor, Linn. [Lit. Brit., Bennett 209 ; Darwin 482 ; Kitchener 1197 ; N.C.E. 1, 3 b, 9, 11, 14, 18, 25, 35, 40 ; Scand., Wittrock 2592; Alps 9,34; Pyren. 17.] The following statement shows it to be at Clova a neglected beeflower ; it is not abundant, and owes its position high up the glen perhaps to cultivation. Verhoeff points out the possibility of self-pollination in the Friesian islands and the frequency with which the spur is bitten through for its honey.

Visitors. Lepidoptera. Rhopalocera: (I) Pieris napi L., sh. I7. VII. 95, $800 \mathrm{ft}$. Diptera. Anthomyïdae: (2) Hyetodesia incana W., I9. VI. $95,800 \mathrm{ft}$.

102. Viola lutea, Smith. [Lit. Brit. 39 ; Scand. 34.] A neglected bee-flower. Bombi and butterflies are recorded as visiting it near Stockholm. On the hundreds of thousands of flowers seen by us at Clova, but fifty insects have been recorded, representing sixteen species, mostly flies which sit on the flower licking the hairs at the mouth of the tube or feeding on pollen. Four species of Lepidoptera were seen on the flowers, each once. The flowers are almost always wholly yellow, and all turn towards the south. The spur is $5^{-6} \mathrm{~mm}$. long.

Visitors. Lepidoptera. Rhopalocera: (I) Pieris napi L., 24. V. 96, $800 \mathrm{ft}$. (2) Lycaena icarus Rott., sh. I 8. VII. 96, $800 \mathrm{ft}$. Heterocera: Tineidae: (3) Glyphipteryx fuscoviridella Haw., sh. 2. VII. 95, $900 \mathrm{ft}$. Eriocephalidae: (4) Eriocephala calthella L., 2. VII. 95, 800 ft. Hymenoptera. Aculeata: Apidae: (5) Andrena analis Panz., 22. VI. 96, I,000 ft. Diptera. Syrphidae: (6) Sphaerophoria sp., 6. VII. 94. Bibionidae: (7) Dilophus sp., 19. V. 97, $800 \mathrm{ft}$. Muscidae: (8) Pollenia rudis F., licking the hairs at the mouth of the tube, $2 \mathbf{I}$. V. 96, 800 ft. Anthomyiidae: (9) Drymia hamata Fln., sh. 4. VII. 95, $800 \mathrm{ft}$. (Iо) Hyetodesia incana W., 2 I. VI. 95, $800 \mathrm{ft}$. (I I) Anthomyia sulciventris Ztt., seeking h. and fp. I9-2 7. V. 97, г6. V. 98, 
7-800 ft. ( 12 and $\mathrm{r}_{3}$ ) A. 2 spp., fp. 4. VII. and 2 I. IX. 95 ; ro. VI. 99 , 7-I,500 ft. (I 4) Coenosia sp., I. VII. 95, $900 \mathrm{ft}$. Cordyluridae: (I5) Scatophaga stercoraria L., 4. VII. 95, $800 \mathrm{ft}$. (I6) I sp., 2. VII. 95, $800 \mathrm{ft}$.

Class H $§ 16$. ORChis TyPe.

103. Orchis maculata, Linn. [Lit. Brit., Darwin 483 ; N.C.E. 1, 3 a, 14, 18, 34, 40 ; Warnstorf 2506; Alps 2.] A bee-flower apparently much neglected about Clova. The spur contains no free honey and requires a breaking of the tissues to yield any sweet juice.

Visitors. Lepidoptera. Rhopalocera: (I) Pieris napi L., seeking h. 19. VI. 96, I,500 ft. Diptera. Anthomyiidae: (2) Hylemyia variata Fln., seeking h. 2 I. V. 95, $800 \mathrm{ft}$. (3) H. nigrescens Rnd., sitting on flower, I6. VI. $99,800 \mathrm{ft}$.

I04. Orchis mascula, Linn. [Lit. Brit., Darwin 483; N.C.E. 1.]

Visitors. Diptera. Anthomyizdae: (I) One sp., 22. VI. 95, I,400 ft. Cordyluridae: (2) Scatophaga stercoraria L., 5. VII. 94, $800 \mathrm{ft}$.

Class H $\$ 17$. Tropaeolum Type.

I05. Tropaeolum speciosum, Poepp. and Endl. In cultivation.

Visitors. Hymenoptera. Aculeata: Apidae: (I) Bombus agrorum F., sh. 19. IX. 95, $800 \mathrm{ft}$.

\section{Class H $\$$ i 8 . Pinguicula Type.}

106. Pinguicula vulgaris, Linn. [Lit. N.C.E. 14; Buchenau in Bot. Zeitung, 1865 , p. 95; Hildebrandt 1041 ; Arct. 36, 38 ; Warming 2498; Alps 2, 9.] A self-fertilizing flower, abundant, but as neglected by insects about Clova as elsewhere. Lindman remarks the great rarity of visitors. Sprengel, Kerner, and Warming describe the way in which the stigma rolls back on to the anthers, and in sections of the flower we have seen the pollen-tubes passing into the stigmatic tissue. Abnormal flowers are very common; in these it is usual for the number 
of lobes of the corolla to be increased. Lindman speaks of it being frequently abnormal, and he also notices the occurrence in the Dovrefjeld of flowers which are almost cleistogamic. At Clova it is very frequently abnormal, generally by the addition of extra lobes to the corolla.

Visitors. Lepidoptera. Rhopalocera: (I) Pieris napi L., sh.going from flower to flower, I5. VI. 99, $800 \mathrm{ft}$. Hymenoptera. Aculeata : Apidae: (2) Bombus lapponicus F., settled on a flower but did not stay to sh. I. VII. 96, 2,000 ft. Diptera. Anthomyizdae: I sp., seen settled on flowers on five occasions, 27. VI. 96, 10. VI. 99, $8-2,500 \mathrm{ft}$.

\section{Class H $\S$ ig. Pedicularis Type.}

107. Pedicularis sylvatica, Linn. [Lit. Brit. 23; Ogle 1904; N.C.E. 1,3 c, 4, 12, 14, 18, $21 \mathrm{~b}, 34$.] The position of the flowers of this species is constant, the hood always above and vertical. The tube is $14-16 \mathrm{~mm}$. long.

Visitors. Lepidoptera. Rhopalocera: (I) Pieris napi L., sh. 19. VI. 96, I5. VI. 99, 8-I,500 ft. Hymenoptera. Aculeata: Apidae: (2) Bombus lapponicus F., seeking h. I I. VII. 96, $800 \mathrm{ft}$. once. (3) B. jonellus Kirby, ? sh. 22. VII. 95, I,200 ft. once. Diptera. Anthomyiidae: (4) Anthomyia sulciventris Ztt., seeking h. or p. 23. V. 97, $900 \mathrm{ft}$.

108. Pedicularis palustris, Linn. [Lit. Brit. $23 ;$ N.C.E. 4, 8, 14, 16, 18, 21 a ; Arct. 36 ; Alps 2.] The position of the flowers is not constant. No one has seen this plant richly visited.

Visitors. Diptera. Syrphidae: (1) Rhingia campestris, Mg., sh. 2. VII. $95,800 \mathrm{ft}$.

Io9. Melampyrum pratense, Linn. [Lit. Brit. $23 ;$ N.C.E. $1,3 \mathrm{c}, 4,16,18,21 \mathrm{~b}, 32,33,34,40$; Alps 9.] A flower distinctly suited to Bombi, but not much visited.

Visitors. Hymenoptera. Aculeata: Apidae: (I) Bombus Iapponicus F., sh. 27. VI. 95, 2,100 ft. 


\section{Class H § 20. 'Labiate' Type.}

IIo. Euphrasia officinalis, Linn. [Lit. Brit. 23; N.C.E. 1, 3 c, 4, 14, 18, 21 b, 30, 40; Wettstein 2539; Arct. 36, 37 c, 38; Alps 2, 9, 21 b, 34; Wettstein 2539; Pyren. 1\%.] The flower varies considerably in size, but the mechanism does not change. In the glen the tube is usually $2.5 \mathrm{~mm}$. long.

Visitors. Hymenoptera. Aculeata: Apidae: (I) Apis mellifica L., sh. I5. IX. 95, $800 \mathrm{ft}$. once. Diptera. Syrphidae: (2) Platychirus manicatus Mg., fp. I4. IX. 95, $800 \mathrm{ft}$.

III. Nepeta Glechoma, Benth. [Lit. Brit. 23, 29, 34; Bennett 212 ; Marquand 1513 ; N.C.E. 1, 3 c, 4, 16, 18, 21 a, $21 \mathrm{~b}, 33,34,40$; De Vries 2460; Alps 34; N.Am. 19 c.] Gynodioecious; the tube of the flower is $4 \mathrm{~mm}$. long.

Visitors. Hymenoptera. Aculeata: Apidae: (I) Apis mellifica L., sh. 20. V. 97, $800 \mathrm{ft}$. Diptera. Anthomyiidae: (2) Anthomyia sp., fp. 20. V. $97,800 \mathrm{ft}$.

II2. Prunella vulgaris, Linn. [Lit. Brit. 23, 39 ; Ogle, 1904 ; N.C.E. 1, 3 c, 4, 11, 14, 14 a, 16, 18, 21 a, 21 b, 30, 32, 34; De Vries 2460; MacLeod 1473; Arct. 34; Alps 2, 16, $21 \mathrm{~b}, 34 ;$ Pyren. $17 ;$ N.Am. $19 \mathrm{c}$.] The tube of the decidedly proterandrous flower is usually 9-10 $\mathrm{mm}$. long. We found, however, a larger-flowered form on the crags at 2,0002,800 feet.

Visitors. Hymenoptera. Aculeata: Apidae: (r) Bombus hortorum L., sh. II. VII. 96, $800 \mathrm{ft}$.

I13. Stachys palustris, Linn. [Lit. Brit. 23; N.C.E. 1, 3 c, 4, 8, 11, 18, 21 b, 32, 33; Alps 16; Pyren. 17.]

Visitors. Hymenoptera. Aculeata: Apidae: (I) Bombus agrorum F., sh. 2. VII. 95. Diptera. Syrphidae: (2) Rhingia campestris Mg., sh. and fp. 2-6. VII. 95. All at $800 \mathrm{ft}$.

II4. Galeopsis Tetrahit, Linn. [Lit. Brit. 23,$39 ;$ N.C.E. 1, 3 c, 4, 18, 21 b, 33, 40 ; Alps 2, 9, 34; Briquet 293; Pyren. 17.] The form with rose flowers is very rare.

Visitors. Lepidoptera. Rhopalocera: (I) Lycaena icarus Rott., P p 
sh. 5. VII. 95, 800 ft. (2) Coenonympha pamphilus L., sh. 5. VII. 95, $800 \mathrm{ft}$. each once. Hymenoptera. Aculeata: Apidae: (3) Bombus terrestris L., sh. I6-I 7. IX. 95, 7-800 ft. (4) B. agrorum F., sh. 5. VII. and I3. IX. 95, 7-800 ft. Diptera. Syrphidae: (5) Melanostoma mellinum L., fp. 22. IX. 95, $800 \mathrm{ft}$. (6) Platychirus albimanus F., fp. I6-I 7. IX. 95, $800 \mathrm{ft}$. (7) P. manicatus Mg., fp. 5. VII. 95, $800 \mathrm{ft}$. Muscidae: (8) Calliphora erythrocephala Mg., fp. 5. VII. 95, $800 \mathrm{ft}$. Anthomyiidae: (9) Anthomyia sp., fp. I7. IX. 95, $800 \mathrm{ft}$. (Iо) Trichophthicus sp., fp. I6. IX. 95, $800 \mathrm{ft}$. Coleoptera. (I I) Meligethes viridescens F., I6-I 7. IX. 95, $800 \mathrm{ft}$.

II5. Lamium purpureum, Linn. [Lit. Brit. 23, 29, 34 ; Bennett 212 ; N.C.E. 1, 3c, 4, 11, 14, 16, 18, 21 b, 34, 40 ; De Vries 2460 ; Alps 34.] The flower is proterandrous; the stigma gradually passes above the stamens to a point beyond them, but not so much as to make self-fertilization impossible.

Visitors. Diptera. Syrphidae: (I) Platychirus discimanus Lw., ? fp. I 5. V. $98,800 \mathrm{ft}$.

II6. Lamium maculatum, Linn. [Lit. N.C.E. $1,3 \mathrm{c}, 4$, $21 \mathrm{~b}, 33,34,35$; Alps 2, 34.] This plant has been established since at least I 840 without spreading to any extent. Some Bombus, not seen by us in the act, bores the corolla, and Apis makes use of the holes.

Visitors. Hymenoptera. Aculeata: Apidae: (I) Apis mellifica L., cp. 20 . V. 97 , and sh. through holes in corolla and cp. hanging under hood, 7-I 5. V. 98 . (2) Bombus hortorum L., sh. 22. V. 97. (3) B. agrorum F., sh. 23. V. 97, I I. VI. 99. Diptera. Syrphidae: (4) Platychirus sp., fp. 23. V. 97. Muscidae: (5) Lucilia cornicina F., 7 . V. 98. Anthomyïdae: (6) Anthomyia sp., fp. г6. V. 98. All at $800 \mathrm{ft}$.

II7. Ajuga reptans, Linn. [Lit. Brit. 23 ; N.C.E. 1, 3 c, 4 , 16, 18, 21 a, 21 b; 33, 40 ; Alps 2, 34; Pyren. 17.]

Visitors. Hymenoptera. Aculeata: Apidae: (I) Bombus agrorum F., sh. 24. VI. 95, 1 0. VI. 99, 7-800 ft. Diptera. Anthomyiidae: (2) I sp., fp. ro. VI. 99, $700 \mathrm{ft}$. 


\section{Class H $\S 2 \mathrm{I}$. Explosive Leguminous Type.}

II8. Genista anglica, Linn. [Lit. N.C.E. 1, $3 \mathrm{~b}, 14,14 \mathrm{a}$, 34, 40.] A species little visited at Clova, where the genera of mid-tongued Hymenoptera observed on it by Müller, Alfken, and Höppner are poorly represented.

Visitors. Hymenoptera. Aculeata: Apidae: (I) Apis mellifica L., cp. 2. V. 97, 7-800 ft. (2) Bombus terrestris L., cp. and seeking h. 25 . V. $97,800 \mathrm{ft}$. (3) B. lapponicus F., seeking h. 22. V. $97,700 \mathrm{ft}$. Diptera. Anthomyiidae: (4) Anthomyia sulciventris $Z \mathrm{tt}$., fp. and seeking h. 20-22. V. 97, 8-900 ft.

I19. Ulex europaeus, Linn. [Lit. Brit. 23, 29; Ogle $1905 ;$ N.C.E. 8, 14, 18, 33.] Apis is a more frequent visitor than the Bombi, but both genera are regular visitors in Scotland and in England. Apis visits the flowers abundantly in Flanders. After explosion a variety of flies find pollen enough to attract them. Many times we have seen the Bombi and Apis thrusting their proboscis into the base of the flower seeking for honey.

Visitors. Hymenoptera. Aculeata: Apidae: (I) Apis mellifica L., cp. and seeking h. 2 I. V. 96, 20-22. V. 97, 7-I6. V. 98 , го. VI. 99, 6-900 ft. (2) Bombus terrestris L., cp. and seeking h. 20-27. V. 97, I0-1 9. VI. 99, 7-800 ft. (3) B. lapponicus F., seeking h. 20-27. V. $97,7-800 \mathrm{ft}$. (4) B. agrorum F., 27. V. $97,800 \mathrm{ft}$. Diptera. Syrphidae: (5) Syrphus sp., fp. 20-27. VI. 97, $800 \mathrm{ft.}$ Muscidae: (6) Pollenia vespillo F., fp. 27. V. 97, 800 ft. Anthomyiidae: (7) Anthomyia sulciventris Ztt., fp. 19-27. V. 97, 7-900 ft. (8) A. sp., fp. on exploded flowers, I6. V. 98, $700 \mathrm{ft}$. Thysanoptera. (9) Thrips sp., 2I. V. $97,800 \mathrm{ft}$.

120. Cytisus scoparius, Link: [Lit. Brit. 23, 34; Henslow 990 ; Darwin 991 ; N.C.E. 1,3 b, 14, 16, 18, 25, 33, 34, 40 ; De Vries 2460.] The flowers are very well visited, the bees (Apis and Bombi) proceeding from flower to flower regularly. Apis is more abundant than the Bombi: second in abundance is Bombus terrestris ; Anthomyiids and Meligethes viridescens are very common on exploded flowers. It is obvious, as 
Müller remarks, that the flower is more sure of advantage from the visits of Bombi than of Apis; but at Clova, in Flanders, Westphalia, \&c., the latter is the more abundant visitor.

Visitors. Hymenoptera. Aculeata: Apidae: (I) Apis mellifica L., cp. and seeking h. I9. VI. 95, 21-22. V. 96, 24. V. 97, IO. VI. 99, 7-800 ft. freq. (2) Bombus terrestris L., cp. and seeking h. 2 I22. V. $96,22-27$. V. 97, I6. VI. $99,7-800 \mathrm{ft}$. freq. (3) B. lapponicus F., sp. and seeking h. 23 . VI. $96,800 \mathrm{ft}$. once. (4) B. agrorum F., seeking h. 2 I. VI. 95, 800 ft. once. (5) B. pratorum L., Io. VI. 99, $800 \mathrm{ft}$. once. Myrmicidae: (6) Myrmica rubra L., seeking h. 23. VI. $95,800 \mathrm{ft}$. once. Formicidae: (7) Formica fusca Latr., seeking h. 23. VI. 95, $800 \mathrm{ft}$. once. Diptera. Syrphidae: (8) Syrphus ? ribesii L., seeking h. I 7-23. VI. 95, $800 \mathrm{ft}$. and ? the same once at 2,300 ft. Muscidae: (9) Calliphora sp., I7. VI. 95, 2,300 ft. Anthomyïdae: (ro) Hyetodesia incana W., seeking h. I 7. VI. 95, 2,300 ft. (I I) Anthomyia sp., fp. 19-23. V. 97, г6. VI. 96, 20-26. V. 97, го. VI. 99, 7-800 ft. (I 2) Trichophthicus sp., fp. I 9-23. V. 97, 7-800 ft. (I3) Azelia aterrima Mg., seeking h. I 7. VI. 95, 2,300 ft. Sapromyzidae: (I4) Lauxania cylindricornis F., 23. VI. 95, $800 \mathrm{ft}$. (I5) L. elizae Mg., 23. VI. 96, $800 \mathrm{ft}$. Coleoptera. (I6) Meligethes viridescens F., fp. I 5. VI. 95, 24. VI. 96, го. VI. 99, 800 ft. (I7) M. aeneus F., I 5. VI. 95, $800 \mathrm{ft}$. (I 8 ) Anthobium torquatum Marsh., seeking h. 23. VI. 95, 24. VI. $96,800 \mathrm{ft}$. (19) Ceuthorrhynchidius sp., ? sucking the juice of the flower, 24. VI. $96,800 \mathrm{ft}$. Hemiptera. (20) Heterocordylus tibialis Hahn., I9-23. VI. 95, 8-900 ft. freq.

\section{Class H $\S 22$. Leguminous Type.}

121. Cytisus Laburnum, Linn. [Lit. N.C.E. 1, 9, 33, 40.] In cultivation. As honey is obtained by boring the tissues the range of visitors is narrowed considerably, for none but Apis and Bombi find how to obtain it.

Visitors. Hymenoptera. Aculeata: Apidae: (I) Apis mellifica L., ab. (2) Bombus terrestris L. (3) B. lapidarius L. All sucking the juices of the flower, 21 . V. $96,800 \mathrm{ft}$.

122. Trifolium pratense, Linn. [Lit. Brit. 23; Darwin 482 ; N.C.E. 1,3 b, 11, 14, 14 a, 15, 16, 18, 21 b, 25, 30, 31, 
32, 33, 34, 40 ; De Vries 2460 ; Arct. 36; Alps 2, 34; Pyren. $17 ; N . A m .19$ a.] Contrasting it with T. repens the effect of the greater length of the tube in inviting long-tongued Hymenoptera and Lepidoptera is evident. According to Verhoeff insects on the Friesian coast require tongues III $2 \mathrm{~mm}$. long, and to Müller $9 \mathrm{~mm}$. long; at Clova $8 \mathrm{~mm}$. would suffice. Apis and some of the shorter-tongued Bombi and other Hymenoptera are recorded as obtaining honey by perforation of the calyx. A honey-bird visits it in the United States. Our observations need extending.

Visitors. Hymenoptera. Aculeata: Apidae: (I) Bombus terrestris L., sh. 22. IX. 95, 800 ft. (2) B. venustus Smith, sh. I I. VII. 96, 700 ft. Diptera. Bibionidae: (3) Bibio pomonae F., seeking h. II. VII. 96, $700 \mathrm{ft}$. Muscidae: (4) Lucilia cornicina F., fp. 5. VII. 95, $700 \mathrm{ft}$. Anthomyizdae: (5) Anthomyia sulciventris Ztt., fp. 2. VII. 95, $900 \mathrm{ft}$. (6) A. sp., fp. 22. IX. 95, 800 ft. Coleoptera. (7) Meligethes viridescens F., cp. and fp. 23. VI. 95, $800 \mathrm{ft}$. Each once.

123. Trifolium hybridum, Linn. [Lit. N.C.E. 3 b, 9, 33, 34; Kirchner 1183.] Cultivated, and well visited by Apis.

Visitors. Hymenoptera. Aculeata: Apidae: (I) Apis mellifica L., sh. 5. VII. and 22. IX. 95, 25. VI. 96, 7-800 ft. Diptera. Muscidae: (2) Lucilia cornicina F., fp. 5. VII. 95, $700 \mathrm{ft}$.

124. Trifolium repens, Linn. [Lit. Brit. 23 ; Darwin 468 and 482 ; Marquand 1513 ; N.C.E. $1,3 \mathrm{~b}, 4,11,14,14 \mathrm{a}, 15$, 16, 18, 25, 30, 31, 32, 33, 34, 40 ; De Vries 2460 ; Arct. 34, 36 ; Alps 2, 34; Pyren. 17.] A Bombus-flower which by the accessibility of the honey attracts Apis in great numbers. In Arctic Norway Bombi are its only recorded visitors; they are the most abundant visitors in the Alps and in the Pyrenees. In North Central Europe and in Britain where bees are kept Apis is perhaps more frequent than the Bombi. Darwin demonstrated in England the need of insect aid in pollination.

Visitors. Lepidoptera. Rhopalocera: (I) Coenonympha pamphilus L., sh. 22. VI. 95, $800 \mathrm{ft}$. (2) Lycaena icarus Rott., sh. 26. VI.-I. VII. 95, Iо. VII. 96, 800 ft. Heterocera: Geometridae: (3) Cam- 
ptogramma ?, sh. I I. VII. 96, $700 \mathrm{ft}$. Hymenoptera. Aculeata: Apidae: (4) Apis mellifica L., sh. 24. VI.-2 2. VII. 95, 5-II. VII. 96, 7-800 ft. (5) Bombus pratorum L., sh. 4. VII. 95, 800 ft. (6) B. lapponicus F., sh. 20. VI. 95, I8. VI.-I0. VII. 96, 8-2,300 ft. (7) B. agrorum F., sh. 22. VI.-6. VII. 95, $800 \mathrm{ft}$. (8) B. venustus Smith, sh. 26. VI. 95, $800 \mathrm{ft}$. Diptera. Empidae: (9) Empis tesselata F., sh. 5. VII. 95, $800 \mathrm{ft}$. Bibionidae: (го) Bibio pomonae F., ? fp. I I. VII. $96,700 \mathrm{ft}$. Cordyluridae: (I I) Scatophaga maculipes Zett., ? fp. 2. VII. $95,800 \mathrm{ft}$.

125. Lotus corniculatus, Linn. [Lit. Brit. 23, 34; Farrer 653 ; N.C.E. 1, 3 b, 11, 12, 14, 14 a, 15, 16, 18, 21 b, 25, 30, 32, 33, 34; Warnstorf 2507; Alps 2, 9, 16, 34; Pyren. 17; Medit. 34.] A Bombus-flower, fertilized at Clova by B. lapponicus and $B$. agrorum. The butterflies, which visit, are to it robbers. The tongue of Apis is hardly long enough to reach the honey. Kerner speaks of dark-coloured flowers occurring at high levels; once we found such at $2,400 \mathrm{ft}$.

Visitors. Lepidoptera. Rhopalocera : (I) Argynnis aglaia L., sh. 23. VI. 95, $900 \mathrm{ft}$. once. (2) Lycaena icarus Rott., sh. 22. VI.-8. VII. 95, I8. VI.-I0. VII. 96, 7-I,000 ft., the male much more freq. than the female. Heterocera: Geometridae: (3) Fidonia atomaria L., I 5. VI. 99, I, I00 ft. (4) Another sp. I 5. VI. 99, I 2-I,500 ft. Hymenoptera. Aculeata: Apidae: (5) Apis mellifica L., sh. I6. VI. 95, 700 ft. (6) Bombus terrestris L., sh. I-8. VII. $95,800 \mathrm{ft}$. (7) B. pratorum L., 26. VI. 95,800 ft. (8) B. lapponicus F., cp. and sh. 26 . VI.-I. VII. 95, 22. VI.-IO. VII. 96 , I 9. VI. $99,8-2,300 \mathrm{ft}$. (9) B. lapidarius L., sh. 6-I I. VII. 96, $800 \mathrm{ft}$. (I0) B. agrorum F., sh. and cp. 25. VI.-23. VII. 95, I 4-I 5. VI. 99, 8-1,100 ft. (II) B. venustus Smith, sh. I6. VI.-II. VII. 96, 700 ft. (I 2) B. hortorum L., sh. I5. VI. 99, $800 \mathrm{ft}$. Petiolata tubulifera: Vespidae: (13) Odynerus pictus Curt., 25. VI. 95, $800 \mathrm{ft}$. Diptera. Tachinidae: (14) Siphona geniculata Deg., seeking h. I6. VI. 99, $800 \mathrm{ft}$. Muscidae: (15) Calliphora sp., seeking h. 15. V. 95, 900 ft. Anthomyiidae: (I6) Hyetodesia incana W., 22. VI. 95, $800 \mathrm{ft}$. (I 7) Drymia hamata Fln., 26. VI. 96, 2,300 ft.

126. Oxytropis campestris, DC. [Lit. Arct. 7;Alps 2, 16.] The flower is usually creamy white with two yellow 
patches on the standard and a purple tip to the keel, not pure white as stated in Trans. Bot. Soc. Edin., xviii. 39I ; but it is whiter and larger than the usual form of the Eastern Alps. The colour varies from this creamy white to a pale lemonyellow or a pale violet. The flower has a sweet scent and abundant honey. The calyx-tube is $7 \mathrm{~mm}$. long, and its teeth an additional $2 \mathrm{~mm}$., and is rather thin, so that it offers but little resistance to the insects which rob the honey by biting through it. The narrow part of the flower is Io $\mathrm{mm}$. long. The passages to the honey between the bases of the stamens are very long. The stigma stands $\mathrm{I} \mathrm{mm}$. above the stamens, and is touched by its own pollen. Rubbing appears to be necessary to make it receptive. The rough areas on the petals, which afford a foothold to insects, have been fully described by Loew for O. pilosa (Flora, I89I, p. 84). In plants from Clova they are distributed as follows: standard very smooth below, less so above on the inner face; wings very rough on the surface directed upwards, especially towards the interlocking processes; keel slightly rough on both sides towards the tip, perfectly smooth below, and rather smooth along the middle line. The plant fruits very freely.

Visitors. Hymenoptera. Aculeata: Apidae: (I) Bombus lapponicus F., sh. 26. VI.-2. VII. 96, 2,300 ft. Formicidae: (2) Formica fusca Latr., seeking h. 26. VI. 96, 22-2,300 ft. Petiolata parasitica : (3) I sp., seeking h. 26. VI. 96, 2,200 ft. Diptera. Bibionidae: (4) Scatopse sp., fp. 26. VI. 96, 22-2,300 ft. Anthomyïdae: (5) Limnophora solitaria Ztt., seeking h. 26. VI. 96, 2,200 ft. Sapromyzidae: (6) Sapromyza sp., seeking h. 2. VII. 96, 2,300 ft. Coleoptera. (7) Meligethes aeneus F., seeking h. 2. VII. $96,2,300 \mathrm{ft}$. (8) M. viridescens F., fp. 26. VI. 96, 22-2,300 ft. Thysanoptera. (9) Thrips sp., 22. VI.-2. VII. 96, 22-2,300 ft. very ab.

127. Vicia Cracca, Linn. [Lit. Brit. 23 ; N.C.E. 1, 3 b, 8, 14, 18, 21 b, 32, 33, 34, 40; De Vries 2460;Arct. 36;Alps 2, 9, 16, $21 \mathrm{~b}$; Pyren. 17.] A Bombus-flower with honey attainable to all the Bombi, but not readily to Apis; rare at Clova. The calyx is sometimes bitten through. The tubular part of the flower is $5-6 \mathrm{~mm}$. long. 
Visitors. Hymenoptera. Aculeata: Apidae: (I) Bombus terrestris L., sh. I I. VII. 96, $700 \mathrm{ft}$. Diptera. Sarcophagidae: (2) Sarcophaga sp., sh. through boring in the calyx, II. VII. $96,700 \mathrm{ft}$.

128. Vicia sylvatica, Linn. [Lit. Brit. 23.] The flowers are so massed together that the plant is very conspicuous, and there is a sweet scent. The petals are veined with mauve. The stigma projects a trifle beyond the anthers, and the style has a long brush of sweeping hairs. If rubbed the stigma leaves a sticky streak, and does not become self-fertilized in the absence of insect visitors. Hence the mechanism of the flower seems to be that suggested for the genus by $\mathrm{H}$. Müller. The petals are $16-18 \mathrm{~mm}$. long, and the narrow part of the flower IO-I $2 \mathrm{~mm}$. The honey is secreted in the position usual for the genus. We have seen the calyx with a hole bitten through it. Schulz, in error, states that Darwin observed bees to bite through the calyx; the plant referred to is, however, Lathyrus sylvestris. Scott Elliot observed Bombus muscorum and $\mathrm{B}$. hortorum as visitors.

Visitors. Hymenoptera. Aculeata: Apidae:(I) Bombus lapponicus F., seeking h. and cp. Io. VII. 96, 2,300 ft. Petiolata tubulifera: Vespidae: (2) Odynerus sp., sh. through borings in calyx, I0. VII. 96, 2,300 ft. Diptera. Bibionidae: (3) Dilophus albipennis Mg., sh. through borings in calyx, 26. VI. 96, 2,300 ft. Anthomyizdae: (4) r sp., seeking h. 2. VII. 96, 2,300 ft. Sapromyzidae: (5) Sapromyza sp., sh. through borings in calyx, ro. VII. 96, 2,300 ft. Coleoptera. (6) Meligethes viridescens F., 26. VI. 96, 2,300 ft. (7) M. aeneus F., seeking h. 10. VII. $96,2,100 \mathrm{ft}$. Thysanoptera. (8) Thrips sp., 26. VI. $96,2,300 \mathrm{ft}$.

129. Vicia sepium, Linn. [Lit. Brit. 23; N.C.E. 1, 3 b, 11, 16, 18, $21 \mathrm{~b}, 33,34,40$; De Vries 2460; Alps 2, 9, 34; Pyren. 17.] Vicia sepium is, as Müller points out, a Bombusflower in which the honey is too difficult of access for Lepidoptera, and to Bombus terrestris is most readily obtained by a biting through of the calyx. We have found bitten flowers at Clova; and they have been noted abundantly by Müller, Schulz, Knuth, and Alfken in Germany, and by MacLeod in 
Flanders. Myrmica rubra was seen (24. VI. 95) on the stipules apparently on account of the honey there.

Visitors. Hymenoptera. Aculeata: Apidae: (I) Bombus venustus Smith, sh. Diptera. Anthomyiidae: (2) Hyetodesia incana W., seeking h. Sepsidae: (3) Sepsis cynipsea L., seeking h. All at $800 \mathrm{ft}$. I 8. VI. 96 .

I30. Lathyrus pratensis, Linn. [Lit. Brit. $23 ;$ N.C.E. ], $3 \mathrm{~b}, 14,14 \mathrm{a}, 18,21 \mathrm{~b}, 32,34,40$; Arct. 36; Alps 2, 34; Medit. 34.] A bee-flower, but not freely visited. Fertilization is, however, dependent on insect visits.

Visitors. Hymenoptera. Aculeata: Apidae: (I) Apis mellifica L., sh. I I. VII. 96, $700 \mathrm{ft}$. once. Diptera. Anthomyïdae: (2) Anthomyia sp., fp. 4-5. VII. 95, 800 ft. Hemiptera. (3) Anthocoris ? nemorum L., seeking h. I6. IX. 95, $900 \mathrm{ft}$.

131. Lathyrus macrorrhizus, Wimm. [Lit. Brit. 23; N.C.E. 14, 21 b, 34, 40 ; Loew 1358 ; Pyren. 17.] A Bombusflower needing insect aid for fertilization, and, as it is not freely visited by insects, commonly sterile.

Visitors. Lepidoptera. Rhopalocera : (I) Pieris napi L., sh. Io. VI. 99, $700 \mathrm{ft}$. Hymenoptera. Aculeata: Apidae: (2) Bombus lapidarius L., sh. 2 I. V. $96,800 \mathrm{ft}$. (3) B. agrorum F., I. VI. 97 , I9. VI. 99, $800 \mathrm{ft}$. Diptera. Anthomyiïdae: (4) Anthomyia sulciventris Ztt., seeking h. 24. V. 97, $800 \mathrm{ft}$.

I32. Polygala vulgaris, Linn. [Lit. Brit., Hart. 933; N.C.E. $1,3 \mathrm{~b}, 14,18,21 \mathrm{~b}, 34 ;$ Pyren. 17.] Polygala vulgaris is another neglected bee-flower. Apis and Bombi are recorded-the one or the other-as frequent visitors by Müller in Germany, by MacLeod in the Pyrenees, and (to P. deprena) by MacLeod in Flanders; both have been observed on P. vulgaris by Knuth in the North Friesian islands. At Clova spontaneous self-fertilization is the rule. Self-fertilization likewise is common on the Continent. At Clova the wings are usually bright blue, and, when the flower is open, $7 \mathrm{~mm}$. long. A tongue $4 \mathrm{~mm}$. long is sufficient to reach the honey.

Visitors. Diptera. Muscidae: (I) I sp., 6. VII. 94, about 2,000 ft. 


\section{Class $\mathrm{H} \S 23$. Digitalis Type.}

I33. Digitalis purpurea, Linn. [Lit. Brit. 23, 39 ; Ogle 1904; Darwin 482 ; N.C.E. 1, 4, 21 b, 30,32, 33, 34; Alps 9.] Bees and beetles visit this plant. Contabescence was observed.

Visitors. Hymenoptera. Aculeata: Apidae: (I) Bombus terrestris L., sh. 25 . IX. $95,800 \mathrm{ft}$. and ? 29. VI. 95, I, I00 ft. (2) B. agrorum F., cp. and sh. 5. VII. 95, $800 \mathrm{ft}$. once. (3) B. venustus Smith, sh. I8. VI. 96, 800 ft. once. Diptera. Anthomyiidae: (4) Drymia hamata Fln., 25. VI. 95, $800 \mathrm{ft}$. (5) Anthomyia sp., seeking h. 2 I. IX. 95, $800 \mathrm{ft}$. Coleoptera. (6) Meligethes viridescens F., 2. VII. and 2 I. IX. 95, 800 ft., 29. VI. 96, I I-I,500 ft. freq. Thy. sanoptera. (7) Thrips sp., sh. 2 I. VI. 96, I,500 ft.

I34. Mimulus Langsdorffii, Donn. ( $M$. luteus, auctorum anglorum). [Lit. N.C.E. 1,9; Batalin 147.] Self-pollination occurs in the fall of the corolla by the anthers sliding up the style to the stigma. The stigma is very sensitive. The flower is obviously suited to Bombus-like insects; but the throat is rather low for our British Bombi. We have not seen them to visit.

Visitors. Diptera. Anthomyiidae:(I) Anthomyia sp., sh. 22. VI. $96,800 \mathrm{ft}$.

\section{Class H $\S 24$. ERICA Type.}

I35. Arctostaphylos Uva-ursi, Spreng. [Lit. N.C.E. 34; Arct. 36, 37 a; Alps 2, 9 ; Pyren. 17.] As the snows melt the young inflorescences can be found in the newly cleared patches of ground. The first flowers open in early May, and at mid May the plant is in full flower. These flowers are strongly scented, and are entirely visited by Bombi, chiefly B. lapponicus, which runs along the ground eagerly from bunch to bunch, sucks hanging back downwards, and then flies or crawls off to another plant. A bee, probably Bombus terrestris, often bites the corolla. Seed is freely formed, and ripens in September.

Visitors. Hymenoptera. Aculeata: Apidae: (I) Bombus terres- 
tris L., sh. 20-23. V. 97, I 5-I,900 ft. not infreq. (2) B. lapponicus F., sh. 20-23. V. $97,8-1,900 \mathrm{ft}$. ab.

I36. Vaccinium myrtillus, Linn. [Lit. Brit. 23, 29, 39 ; Ogle 1905 ; N.C.E. 1, 4, 16, 18, 33, 34, 40; Arct. 34, 36 ; Alps 2,34; Pyren. 17.] A very typical bee-flower, attracting Bombus lapponicus in great quantity and other Bombi also. The honey is particularly abundant, and drops appear on the bell within the reach of insects which cannot obtain it from the nectary. Fruit may ripen very abundantly.

Visitors. Lepidoptera. Heterocera: Geometridae: (I) Larentia salicata Hb., sh. 25. VI. 95, 2,300 ft. twice. Hymenoptera. Aculeata: Apidae: (2) Bombus terrestris L., sh. I6. VI.-I 7. VII. 95, 2223. V. 96, 18-27. V. 97, I2. VII. 99, 7-2,300 ft. (3) B. pratorum L., sh. I9. VI. 95, 2,000 ft. (4) B. lapponicus F., sh. I6-25. VI. 95, I 8-2 5. V. 97, I 2. VI. 99, 7-2,400 ft. very ab. (5) B. hortorum L., sh. I 7. VI. 99, 2,500 ft. Formicidae: (6) Formica fusca Latr., seeking h. I 8 . V. 97, I, $900 \mathrm{ft}$. and inside a flower, the edge of which had been eaten, I 2. V. 98, $800 \mathrm{ft}$. Diptera. Empidae: (7) Empis lucida Ztt., 24. V. 97 ; I2. VI. 99, I,600-2,300 ft. Anthomyiidae: (8) Anthomyia sulciventris Ztt., seeking h. 25. VI. 95, 2,300 ft.

I37. Vaccinium Vitis-idaea, Linn. [Lit. Brit. 23, 26; N.C.E. 14, 33, 34, 40; Arct. 7, 36, 37 a, 38; Alps 2, 9.] Bees and hemitropous flies visit this flower. Fruit is set abundantly.

Visitors. Lepidoptera. Heterocera: Noctuidae: (I) Triphaena sp., I 9. VI. 95, 2,000 ft. Hymenoptera. Aculeata: Apidae: (2) Bombus terrestris L., sh. 24. IX. 95, r, $200 \mathrm{ft}$. (3) B. lapponicus F., sh. 19-27. VI. 95, 20-2,100 ft. (4) Nomada ruficornis L., sh. I 2. VI. 99, I,000 ft. Diptera. Syrphidae: (5) Melanostoma quadrimaculatum Verrall, sh. I9. VI. 95, 2,000 ft. Empidae: (6) Empis lucida Ztt., 19. VI. 95, I3. VI. 99, 19-2,000 ft. (7) E. livida L., sh. 19. VI. 99, 2,000 ft.

138. Erica Tetralix, Linn. [Lit. Brit. 23, 29, 34, 39 ; N.C.E. 1, 3 c, 11, 12, 14, 14 a, 18, 21 a, 30, 35, 40.] Bombi are the chief visitors. By flowering just after midsummer, when butterflies are numerous, it obtains a certain number 
of visits from them. Apis visits it freely. A species of Bombus, probably B. terrestris, bites through the corolla. Abnormally, more or less polypetalous flowers (such as Sigerson described in Proc. Royal Irish Acad., I87 I, Ser. II, vol. i, and Price in Proc. Bot. Soc. Edinb., xi, p. 256) are not uncommon in certain seasons.

Visitors. Lepidoptera. Rhopalocera: (I) Argynnis selene Schiff., sh. 23. VI. 95, $900 \mathrm{ft}$. (2) A. aglaia L., sh. I5-25. VI. 95, I. VII. 96, 9-I,000 ft. (3) Polyommatus phloeas L., sh. I. VII. 95, $800 \mathrm{ft}$. Heterocera: Noctuidae: (4) Celaena haworthii Curt., sh. 23. IX. 95, r,100 ft. Geometridae: (5) Cidaria sp., sh. 2. VII. 95, I, 100 ft. Hymenoptera. Aculeata: Apidae: (6) Apis mellifica L., sh. I7-2 I. VII. 95, 9-I,200 ft. (7) Bombus terrestris L., sh. 23. VI.-23. IX. 95, 22. VI.-9. VII. 96, 8-I,400 ft. ab. (8) B. lapponicus F., sh. 23. VI.-I 9. IX. 95, 8-Io. VII. 96, 8-I,500 ft. (9) B. jonellus Kirby, cp. and sh. $2 \mathrm{I}-22$. VII. 95, II-I,200 ft. (I0) B. agrorum F., sh. 5. VII. and 23. IX. 95, 8-900 ft. (II) B. venustus Smith, sh. 22. VI. $95, \mathrm{I}, 100 \mathrm{ft}$. Vespidae: (I 2) Vespa norvegica F., sh. by means of borings, 2 I-22. VII. 95, I I-I,200 ft. Diptera. Syrphidae: (I3) Eristalis pertinax Scop., 20. IX. 95, 9-I,000 ft. Muscidae: (I 4) Pollenia rudis F., sh. and fp. 22-23. IX. 95, 9-I,IIo ft. Anthomyiidae: (I5) Hyetodesia incana W., 20. IX. 95, 9-I,100 ft. Ortalidae: (I6) Pteropaectria frondescentiae L., seeking h. 6. VII. 95, $900 \mathrm{ft}$. Coleoptera. (I 7 ) Meligethes viridescens F., sh. by means of a boring, 23. IX. 95, I, $100 \mathrm{ft}$.

I39. Erica cinerea, Linn. [Lit. Brit. 23, 26, 29, 34, 39; Ogle 1905; Powell 2020 ; N.C.E. 14, 14 a, 15, 16, 18, 21 a, $21 \mathrm{~b}$.$] Apis visits this plant more freely than it does$ E. Tetralix. Bombi are however the chief visitors, one of them, B. terrestris, often bites through the corolla in order to obtain the honey. Vespa and other short-tongued insects afterwards take advantage of the borings.

Visitors. Lepidoptera. Rhopalocera: (I) Argynnis aglaia L., sh. I8. VI. 96, $800 \mathrm{ft}$. (2) A. selene Schiff., sh. 23. VI. 95, $900 \mathrm{ft}$. (3) Coenonympha pamphilus L., sh. 26. VI. 95, $800 \mathrm{ft}$. (4) Polyommatus phloeas L., sh. I5. IX. 95 and I 8 . VI. $96,800 \mathrm{ft}$. Hymeno. ptera. Aculeata: Apidae: (5) Apis mellifica L., sh. I 7-22. VII. 95, 
9-I,200 ft. freq. (6) Bombus terrestris L., sh. in the proper manner and biting through, 23. VI.-24. IX. 95, r8. VI.-9. VII. 96, 8-1,700 ft. very ab. (7) B. jonellus Kirby, sh. 2 I -22 . VII. 95, II $-\mathbf{I}, 300 \mathrm{ft}$. (8) B. lapponicus F., sh. 25. VI.-I4. IX. 95, I8. VI.-xo. VII. 96, 8-2,300 ft. freq. (9) B. smithanus White, I 4. IX. 95, $800 \mathrm{ft}$. (Io) B. pratorum L., sh. 27. VI. 95, $800 \mathrm{ft}$. (II) Psithyrus quadricolor Lep., sh. 22. VII. 95, I,700 ft. Vespidae: (I2) Vespa norvegica ? F., sh. by means of borings, $2 \mathbf{I}$. VII. 95, III-I,200 ft. twice. Diptera. Syrphidae: (I3) Volucella bombylans L., sh. 23. VI. 95, $900 \mathrm{ft}$. once. Muscidae: (I4) Pollenia rudis F., sh. by means of a boring, I 4. IX. 95, $900 \mathrm{ft}$. once.

\section{Class H $\$ 2.5$. Simple Pendulous Type.}

I40. Geranium phaeum, Linn. [Lit. Brit., Darwin 482 ; N.C.E. 1, 21 b, 33, 34 ; Errera 633 ; Loew 1358 ; Pyren. 17.] Errera found it in Belgium to be a very characteristic beeflower. At Clova Bombus agrorum is a regular visitor, but Syrphids are not infrequent.

Visitors. Lepidoptera. Heterocera: Noctuidae: (I) Habrostola urticae Hb., sh. I 4. VI. 99, 800 ft. Tineidae: (2) Gelechia sp., sh. 26. VI. 95. Hymenoptera. Aculeata: Apidae: (3) Bombus agrorum F., sh. I6-2 I. VI. 95, I0-I2. VI. 99, fairly constant. (4) B. terrestris L., sh. 22. VI. 96, I2. VI. 99. Petiolata tubulifera: Vespidae: (5) Odynerus trimarginatus Ztt., sh. 22. VI. 96. Diptera. Syrphidae: (6) Platychirus manicatus Mg., sh. Io. VI. 99. (7) Rhingia campestris Mg., 17. VI. 96. Empidae: (8) Empis sp., sh. 22. VI. 96. (9) E. punctata Mg., 22. VI. 96. Tachinidae: (10) Siphona geniculata Deg., sh. I8. VI. 96. Anthomyiïdae: (I r) Anthomyia sp., sh. 19-22. VI. 96 . All at $800 \mathrm{ft}$.

I4I. Prunus avium, Linn. [Lit. N.C.E. 1, 3 b, 16, 18, 33.] This tree is very well visited by Bombus lapponicus.

Visitors. Lepidoptera. Rhopalocera: (I) Pieris rapae L., sh. 22. VI. 97, $600 \mathrm{ft}$. (2) Vanessa urticae L., sh. 2 I. V. 97, $600 \mathrm{ft}$. Hymenoptera. Aculeata: Apidae: (3) Apis mellifica L., sh. 2 I. V. 97, $800 \mathrm{ft}$. (4) Bombus lapponicus F., $2 \mathrm{I}-25 . \mathrm{V} .97,800 \mathrm{ft}$. freq. Diptera. Syrphidae: (5) Syrphus punctulatus Verrall, sh. 21. V. 97, 
800 ft. (6) P. discimanus Lw., fp. 2 I. V. 97,800 ft. Empidae: (7) Rhamphomyia cinerascens Mg., sh. 24. V. 97, $800 \mathrm{ft}$. Anthomyiidae: (8) Anthomyia sulciventris Ztt., 2I-25. V. 97, 6-800 ft. Thysanoptera : (9) Thrips sp., in base of the flower, I6. V. 98, $800 \mathrm{ft}$.

142. Rubus Idaeus, Linn. [Lit. Brit. 23 ; N.C.E. 1, 16, 18, 32, 34, 40; MacLeod 1473; Alps 2, 9.] We found moths frequent visitors; MacLeod observed the same in Belgium.

Visitors. Lepidoptera. Heterocera: Bombycidae: (I) Hepialis humili L., sh. 27. VI.-3. VII. 95, 800 ft. Noctuidae: (2) Apamea gemina Hb., sh. 27. VI. 95, $800 \mathrm{ft}$. (3) Dianthecia cucubali Fues., sh. 24-27. VI. 95, $800 \mathrm{ft}$. (4) Xylocampa areola, Esp., sh. 27. VI. 95, $800 \mathrm{ft}$. (5) Habrostola tripartita Hufn, sh. 27. VI. 95, $800 \mathrm{ft}$. (6) Plusia chrisitis L., sh. 27. VI,-6. VII. 95, $800 \mathrm{ft}$. (7) P. festucae L., sh. 27. VI. 95, 800 ft. (8) P. pulchrina Haw., sh. 27-30. VI. 95, $800 \mathrm{ft}$. Geometridae: (9) Cabera pusaria L., sh. 27. VI. 95, $800 \mathrm{ft}$. (10) Thera variata Schiff., sh. 27. VI. 95, $800 \mathrm{ft}$. Hymenoptera. Aculeata: Apidae: (I I) Apis mellifica L., sh. 20-23. VI. 95, $800 \mathrm{ft}$. (I2) Bombus terrestris L., 27. VI. 95, $800 \mathrm{ft}$. (I3) B. pratorum L., 27. VI. 95, $800 \mathrm{ft}$. (14) B. lapponicus F., sh. 3-6. VII. 96, 2I2,300 ft. (I 5) B. agrorum F., sh. 20. VI.-2. VII. 95, i 9. VI. 99, 800 ft. freq. Vespidae: (I6) Vespa norvegica F., sh. 29. VI. 96, $800 \mathrm{ft}$. (I 7) Vespa sylvestris Scop., 27. VI. 95, $800 \mathrm{ft}$. Diptera. Syrphidae: (I8) Sericomyia lapponum L., sh. 23. VI. 95, $800 \mathrm{ft}$. (19) Eristalis arbustorum L., sh. 23. VI. 97, $800 \mathrm{ft}$. Anthomyiidae: (20) Hyetodesia incana W., sh. 21-23. VI. 95, 26. VI. 96, 8-1,000 ft. (2 I) Anthomyia sp., sh. 23. VI. 95, 800 ft. (22) Hydrotaea sp., sh. I 9. VI. 99, $800 \mathrm{ft}$.

143. Geum rivale, Linn. [Lit. Brit. 23 ; N.C.E. 1, 16, 21 a, 21 b, 33, 34; Warnstorf 2507; Arct. 34;Alps 2, 9.]

Visitors. Hymenoptera. Aculeata: Apidae: (I) Bombus lapponicus F., sh. 6. VII. 95, 20. VI.-6. VII. 96, 23-2,500 ft. (2) B. agrorum F., sh. 24. VI. 95, $800 \mathrm{ft}$. (3) Psithyrus quadricolor Lep., sh. 20. VI. 96, 2,400 ft. Diptera. Anthomyiidae: (4) Anthomyia sp., fp. 6. VII. 96, 2,400 ft. Coleoptera. (5) Meligethes viridescens F., sh. 20. VI. $96,2,400 \mathrm{ft}$. 
Class H $\S 26$. Pyrola Secunda Type.

144. Pyrola secunda, Linn. [Lit. N.C.E. 1, 4, 34; Alps 9.] The stigma protrudes from the opening bud, and the stamens seem to force their way between the petals. The openings of the anthers are turned away from the stigma.

Visitors. Hymenoptera. Aculeata: Apidae: (I) Bombus lapponicus F., sh. Coleoptera. (2) Meligethes aeneus F., fp. (3) Epuraea aestiva L., ? fp. All 6. VII. 96, I,900 ft.

145. Ribes sanguineum, Pursh. [Lit. Brit. $29 ;$ N.C.E. 3 a, 40.] In cultivation.

Visitors. Hymenoptera. Aculeata: Apidae: (r) Bombus terrestris L., sh. I 4. V. $98,800 \mathrm{ft}$.

Class $\mathrm{H} \S 27$. Galanthus Type.

146. Galanthus nivalis, Linn. [Lit. N.C.E. 1, 9, 18, 33, 34; Knuth 2871.] In cultivation.

Visitors. Hymenoptera. Aculeata: Apidae: (I) Apis mellifica L., I 5. IV. 95, $800 \mathrm{ft}$.

\section{Class H $\S 28$. Campanula Type.}

147. Campanula rotundifolia, Linn. [Lit. Brit. 23, 34, 39 ; Marquand 1513 ; N.C.E. 1, 11, 14, 14 a, 16, 18, 30, 32, 34, 35; Arct. 36, 38; Alps 2, 34; Pyren. 17.] A flower in a measure specialized for Melitta, Eriades, and Halictoides, and a shelter-flower to small flies, which are abundant in its bells, and also sometimes a shelter-flower to Andrena. Bombi, Apis, Melitta, Cilissa, Eriades, Halictoides, and other similar bees visit the flower in Germany and the Alps; Bombi have been seen on it in Scandinavia and the Pyrenees, and Bombus terrestris in Southern Scotland; it is worth remark that we have seen no bees in the flowers except two species of Andrena. Insects with a tongue of $3 \mathrm{~mm}$. and upwards can reach the honey.

Visitors. Lepidoptera. Heterocera: Pyralidae: (I) Scopula alpi- 


\begin{tabular}{|c|c|c|}
\hline & एँّ & 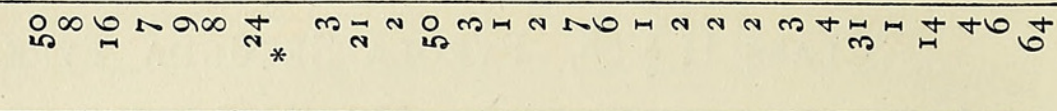 \\
\hline & 离 & ${ }^{n} 1111^{+m} 11^{n}|1| 1|1| 1|1| 1|1| 1|1| 1 \mid 1^{n}$ \\
\hline & $\overrightarrow{0}$ & $=1|x| 101|1| 1|1| 1|1| 1|1|<1|1| 1$ \\
\hline & $\dot{\leftrightarrow}$ & 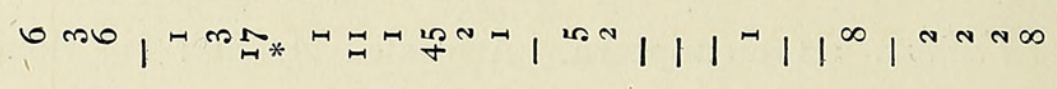 \\
\hline & $\dot{घ}$ & 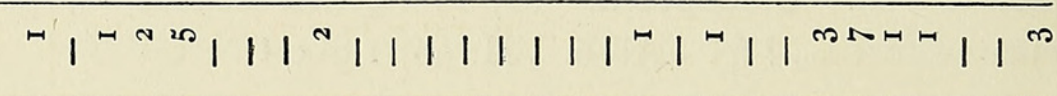 \\
\hline & 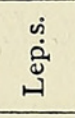 & $|N| 1|1| 1|1|-1|1| 1|1| 1|1| 1|1| 1 \mid$ \\
\hline & 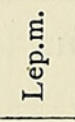 & $m-1|1| 1|1| 1-1|1| 1|1| 1|1| 1|1| 1 \mid$ \\
\hline 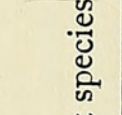 & $\dot{\overrightarrow{0}}$ & 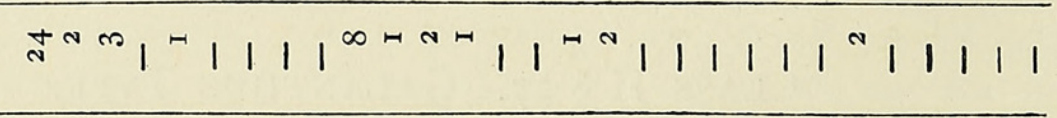 \\
\hline 节 & 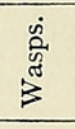 & 1111111111111111111111111111 \\
\hline 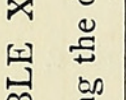 & 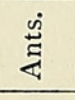 & 11111111111111111111111111111 \\
\hline 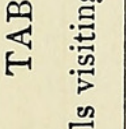 & $\begin{array}{r}\dot{\Xi} \\
\dot{0} \\
\text { 苞 } \\
\end{array}$ & 11111111111111111111111111111 \\
\hline 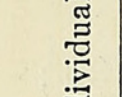 & 离 & 111111111111111111111111111111111 \\
\hline 蔦 & 宾 & $11111111111-11111111111111111$ \\
\hline & $\begin{array}{l}\text { हี } \\
\text { ही }\end{array}$ & 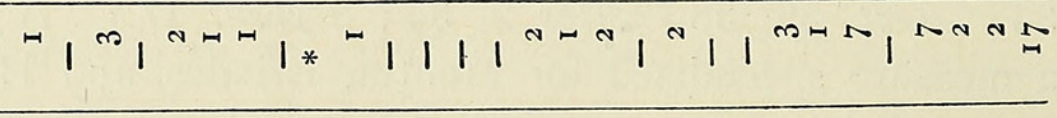 \\
\hline & 离 & $11^{\infty}|1| *|1| 1|1| 1|1| \pi-1|1|+1$ m \\
\hline & & 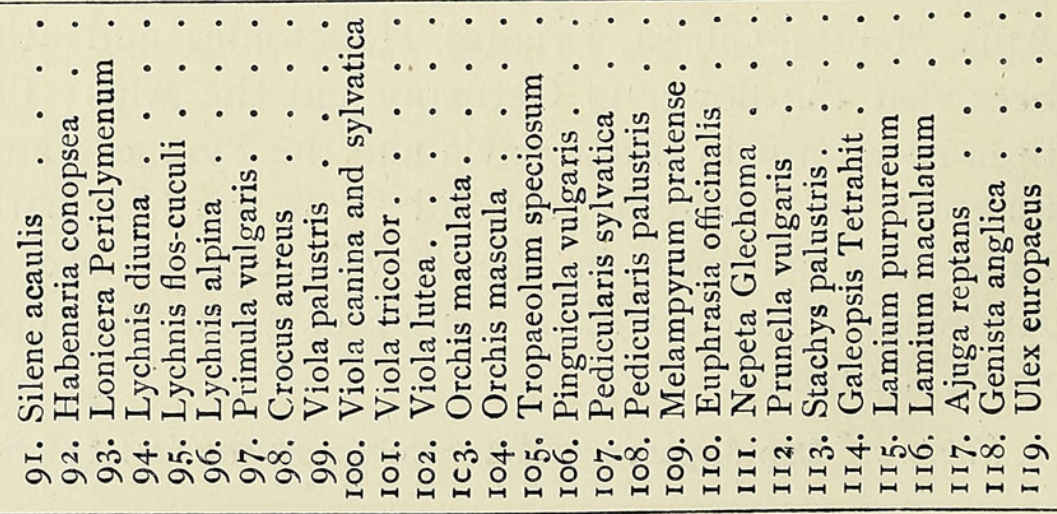 \\
\hline
\end{tabular}







nalis Schiff., sh. 27. VI. 95, 2,000 ft. once. Tineidae: (2) Glyphipteryx fuscoviridella Haw., sh. 27. VI. 95, 800 ft. once. Eriocephatidae: (3) Eriocephala calthella L., 23. VII. 95, $800 \mathrm{ft}$. Hymenoptera. Aculeata: Apidae: (4) Andrena analis Panz, cp. I7. VII. 95, and sh. Io. VII. $96,800 \mathrm{ft}$. (5) A. coitana Kirby, sh. freq. and sheltering (?), 2-23. VII. 95, $800 \mathrm{ft}$. Petiolata parasitica: Cynipidae: (6 and 7) 2 spp., I6. VI. and 23. VII. 95, $800 \mathrm{ft}$. Diptera. Syrphidae: (8) Rhingia campestris Mg., sh. ro. VII. 96, $800 \mathrm{ft}$. once. (9) Platychirus manicatus Mg., sh. 3-I 7. VII. 95, 800 ft. ; 8. VII. 96, 2,400 ft. (Io) Melanostoma mellinum L., 3. VII. 95, $800 \mathrm{ft}$. Tachinidae: (I I) Siphona geniculata Deg., sh. 26. VI. 95; I3-I6. IX. 95, 7-800 ft. Muscidae: (I2) Calliphora erythocephala Mg., sh. Io. VII. 96, $800 \mathrm{ft}$. Anthomyiidae: (13) Drymia hamata Fln., fp. 2. VII. 96, 2,100 ft. (I 4) Anthomyia sp., I6. VI.-23. VII. 95, 8-r,800 ft. ( 15$)$ Trichophthicus hirsutulus Ztt., 6. VII. 96, 2,000 ft. (I6) Trichophthicus sp., sh. and fp. I7-23. VII. 95, $800 \mathrm{ft}$. Thysanoptera. (I 7) Thrips sp., sh. 22. IX. 95, $800 \mathrm{ft}$.

We have had under observation the following flowers of Classes $\mathrm{F}$ and $\mathrm{H}$, but have seen no insects visiting them :-

Polygala serpyllacea, Weihe, Anthyllis vulneraria, Linn., Rubus saxatilis, Linn., Vaccinium uliginosum, Linn., Gentiana campestris, Linn., Rhinanthus Crista-galli, Linn., Habenaria albida, R. Br.; however, from the last-named the pollinia were observed to be regularly removed at night. We have seen in flower at Clova, but have not had suitable opportunities for watching : Lobelia Dortmanna, Linn., Primula veris, Linn., and Utricularia minor, Linn. Silene Cucubalus, Wibel, Vicia hirsuta, Koch, Arctostaphylos alpina, Spreng., and Scrophularia nodosa, Linn., are other Clova plants of Class $\mathrm{H}$ which we have not seen in our district, although we have every reason to believe that they have been observed. Symphytum officinale, Linn., we have observed just outside our limits at 500 feet to be diligently visited by Bombus agrorum.

Out of the whole available anthophilous insect-fauna of (for the time of our observations) 17,306 individuals, 1,507 went to 
Classes $\mathrm{F}$ and $\mathrm{H}$. It is not worth while to separate the two classes here; for there are but three species assigned to $F$, and of them only one (Silene acaulis) appeared as a true Lepidoptera-flower. The species of plants obtained attention as in Table XX. The decidedly desirable insects showed their marked preference; and nearly one half of the total number of individuals of them, which we observed to visit, went to flowers of these two classes, and made 57.73 per cent. of their visitors.

TABLE XXI.

\begin{tabular}{|c|c|c|c|c|}
\hline & \multicolumn{2}{|c|}{ Available. } & \multicolumn{2}{|c|}{$\mathrm{F}$ and $\mathrm{H}$. } \\
\hline & No. & $\%$ & No. & $\%$ \\
\hline Distinctly desirable & 1,763 & I0.19 & 870 & $57 \cdot 73$ \\
\hline Desirable . & 1,277 & $7 \cdot 37$ & 87 & 5.77 \\
\hline Indifferent & I 2,993 & 75.08 & $4^{\mathrm{I}} 3$ & $27 \cdot 4 \mathrm{I}$ \\
\hline Injurious . . & $\mathrm{I}, 273$ & $7 \cdot 36$ & I37 & 9.09 \\
\hline
\end{tabular}

We found that in Class $\mathrm{B}^{\prime}$ the blue-lilac flowers attracted the best of the insects, that the rose-purple came next, that yellow followed, and that white or eyed flowers came last. Experience with Classes $\mathrm{F}$ and $\mathrm{H}$ is different, and our figures are as follows: with white at the top, rose-purple second. yellow third, and lilac-blue last.

TABLE XXII.

\begin{tabular}{|c|c|c|c|c|}
\hline & $\begin{array}{l}\text { Lilac and } \\
\text { blue. }\end{array}$ & $\begin{array}{l}\text { Rose and } \\
\text { purple. }\end{array}$ & $\begin{array}{l}\text { Yellow and } \\
\text { scarlet. }\end{array}$ & White. \\
\hline Decidedly desirable & I 6.66 & $74 \cdot 67$ & $46 \cdot 26$ & $76 \cdot 55$ \\
\hline Desirable . & I 2.35 & $5 \cdot 95$ & I. 77 & $7 \cdot 24$ \\
\hline Indifferent . & $60 \cdot 31$ & $16 \cdot 50$ & $32 \cdot 75$ & I 5.86 \\
\hline Injurious . . & 10.67 & 2.88 & 19.22 & $\cdot 34$ \\
\hline
\end{tabular}

In the table which follows and which amplifies XXI, we have kept Campanula apart, for it certainly is a peculiar type; Q q 2 
but still the lilac-blue flowers remain those which get fewest of the decidedly desirable insects.

TABLE XXIII.

\begin{tabular}{|c|c|c|c|c|c|c|c|c|c|c|c|c|}
\hline & 娄 & है & 岳 & 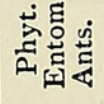 & 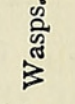 & ه্త & 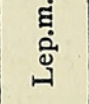 & 灾 & คี & $\ddot{\oplus}$ & $\overline{8}$ & 兽 \\
\hline Campanula & - & - & 12.82 & $I \cdot 7 \mathrm{I}$ & - & - & $\mathrm{I} \cdot 7 \mathrm{I}$ & .85 & 4.27 & 63.25 & - & $15 \cdot 39$ \\
\hline Other blue-lilac flowers & $\mathrm{I} \cdot 45$ & I 3.04 & $\mathrm{I} \cdot 45$ & - & - & 18.84 & $I \cdot 45$ & 2.90 & $2.90^{\circ}$ & $44 \cdot 93$ & 8.70 & $4 \cdot 35$ \\
\hline Rose-purple. . & 12.09 & $54 \cdot 13$ & .I9 & $\cdot 3^{8}$ & $2 \cdot 30$ & $8 \cdot 45$ & .77 & - & 4.99 & $7 \cdot 10$ & 7.10 & $2 \cdot 5^{\circ}$ \\
\hline Yellow & $17 \cdot 24$ & 19.02 & .39 & .98 & - & 10.00 & .20 & .20 & I.I 8 & 25.69 & 6.86 & 18.24 \\
\hline White. • • • & $27 \cdot 93$ & 30.00 & $\cdot 34$ & & 1.03 & I 8.62 & - & - & $6 \cdot 9 \circ$ & 8.97 & 5.86 & $\cdot 34$ \\
\hline
\end{tabular}

In our enumeration of visitors, and in Table XX, we have taken the flowers of Class $\mathrm{H}$ in such order that first come those with erect actinomorphic flowers, secondly those with horizontal zygomorphic flowers, and thirdly, those with pendent actinomorphic flowers. We may add to them the three flowers of Class $\mathrm{F}$-one erect actinomorphic and two horizontal zygomorphic-whereupon we get :-

1. Six erect actinomorphic in which to reach the honey a tongue 4-16 $\mathrm{mm}$. long is required, average $10 \mathrm{~mm}$.

2. Thirty-eight horizontal zygomorphic in which to reach the honey a tongue $4-20 \mathrm{~mm}$. long is required, average $8 \mathrm{~mm}$.

3. Thirteen pendent actinomorphic in which to reach the honey a tongue $\mathrm{I}-7 \mathrm{~mm}$. long is required, average $4.5 \mathrm{~mm}$.

It is very easy to show that a greater exclusion of the undesirable or little desirable insects is effected by the simple inversion of the flower than by lengthening the tube.

TABLE XXIV.

Effect of the position of the flower upon the groups of the visitors.

\begin{tabular}{|c|c|c|c|c|c|c|c|c|c|c|c|c|}
\hline & 离 & हًં & 离 & 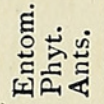 & 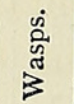 & & 迎 & ه্] & คี & $\stackrel{\infty}{n}$ & i & 离 \\
\hline Erec & - & & - & & - & $25 \cdot 5 \mathrm{I}$ & 3.06 & - & 8.16 & 27.55 & 23.47 & \\
\hline Hori & 23.57 & 19.01 & .39 & .65 & - & 9.64 & .26 & .39 & 2.29 & 22.01 & $7.8 \mathrm{i}$ & I 3.28 \\
\hline Pendent. . & 8. I I & 50.55 & 2.65 & .62 & $2 \cdot 34$ & 9.83 & $\cdot 47$ & .16 & $4 \cdot 37$ & 16.07 & I. 87 & 2.96 \\
\hline
\end{tabular}


TABLE XXV.

Effect of the position of the flower upon the desirability of the visitors.

\begin{tabular}{|c|c|c|c|}
\hline & Erect. & Horizontal. & Pendent \\
\hline Decidedly desirable. & $30.6 \mathrm{I}$ & $52 \cdot 22$ & 68.49 \\
\hline Desirable & II. 22 & 3.64 & $7 \cdot 49$ \\
\hline Indifferent & $5^{1.02}$ & 30.21 & 20.44 \\
\hline Injurions . & $7 \cdot 14$ & I 3.93 & $3 \cdot 5^{8}$ \\
\hline
\end{tabular}

The pendent flowers thus, despite the shallowness of their honey, are seen to get the greater proportion of distinctly desirable insects, this proportion being chiefly made up by Bombi.

It happens that the majority of the white flowers are pendent, all the lilac-blue flowers, except Campanula rotundifolia, are horizontal, and most of the yellow flowers also, while the rose-purple flowers are divided.

TABLE XXVI.

Colour and position of flowers of Classes $\mathrm{F}$ and $\mathrm{H}$.

\begin{tabular}{|l|c|c|c|c|}
\hline & Lilac-Blue. & Rose-Purple. & Yellow-Scarlet. & White. \\
\hline Erect & 0 & 4 & 2 & \\
Horizontai & I4 & IO & I I & 3 \\
Pendent & I & 5 & I & 6 \\
\hline
\end{tabular}

But the observation recorded by means of Tables XXII and XXIII, that white and rose-purple flowers of Classes $\mathrm{F}$ and $\mathrm{H}$ get the best of the insects is, however, not entirely due to so many of the pendent flowers being white or rose-purple; and if we take the horizontal flowers by themselves, the result remains the same, but the differences are somewhat lessened.

By season the distinctly desirable insects get fewer towards autumn, the indifferent get a little fewer, while the desirable and injurious increase, especially the latter. 
TABLE XXVII.

Desirability of visitors to the various colours of the horizontal zygomorphic flowers.

\begin{tabular}{|c|c|c|c|c|}
\hline & $\begin{array}{l}\text { Lilac and } \\
\text { Blue. }\end{array}$ & $\begin{array}{c}\text { Rose and } \\
\text { Purple. }\end{array}$ & $\begin{array}{l}\text { Yellow and } \\
\text { Scarlet. }\end{array}$ & White. \\
\hline Decidedly desirable & $33 \cdot 33$ & 52.08 & $47 \cdot 69$ & 79.53 \\
\hline Desirable. . & $\begin{array}{r}5.80 \\
56.52\end{array}$ & 6.25 & $\begin{array}{r}1.89 \\
1.89\end{array}$ & 7.09 \\
\hline $\begin{array}{l}\text { Indifferent } \\
\text { Injurious . }\end{array}$ & $5^{6 \cdot 5^{2}}$ & $\begin{array}{r}34 \cdot 37 \\
7 \cdot 29\end{array}$ & $\begin{array}{l}29 \cdot 83 \\
20.04\end{array}$ & $\begin{array}{r}13.39 \\
0.00\end{array}$ \\
\hline & & & & \\
\hline
\end{tabular}

TABLE XXVIII.

Visitors to Classes $\mathrm{F}$ and $\mathrm{H}$ by season.

\begin{tabular}{|c|c|c|c|c|c|c|}
\hline & \multicolumn{2}{|c|}{ Spring. } & \multicolumn{2}{|c|}{ Summer. } & \multicolumn{2}{|c|}{ Autumn. } \\
\hline & No. & $\%$ & No. & $\%$ & No. & $\%$ \\
\hline $\begin{array}{l}\text { Distinctly desirable } \\
\text { Desirable. }: . \\
\text { Indifferent }: \\
\text { Injurious . }: \\
\end{array}$ & $\begin{array}{r}2 \text { I I } \\
10 \\
93 \\
6\end{array}$ & $\begin{array}{r}65.94 \\
3 \cdot 12 \\
29.06 \\
1.88\end{array}$ & $\begin{array}{r}605 \\
68 \\
291 \\
\text { I I } 2\end{array}$ & $\begin{array}{r}56 \cdot 23 \\
6 \cdot 3^{2} \\
27 \cdot 04 \\
10 \cdot 41\end{array}$ & $\begin{array}{r}54 \\
9 \\
29 \\
19\end{array}$ & $\begin{array}{r}48.65 \\
8.11 \\
26.13 \\
17 \cdot 12\end{array}$ \\
\hline Total . & 320 & - & 1076 & - & I I I & - \\
\hline
\end{tabular}

The actual numbers and percentages in the different groups are as follows :-

TABLE XXIX.

Visitors to Classes $\mathrm{F}$ and $\mathrm{H}$ by season.

\begin{tabular}{|c|c|c|c|c|c|c|c|c|c|c|c|c|c|}
\hline & 竞 & ڤ̊ & 点 & 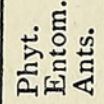 & 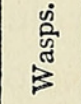 & 离 & 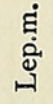 & $\begin{array}{l}\dot{\varphi} \\
\stackrel{\leftrightarrow}{\leftrightarrow} \\
\stackrel{\leftrightarrow}{9}\end{array}$ & ถี & $\ddot{\circ}$ & 3 & 迎 & $\underset{\leftrightarrow}{\text { गुँ }}$ \\
\hline 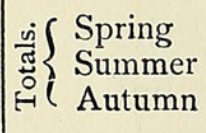 & $\begin{array}{r}62 \\
168 \\
3\end{array}$ & $\begin{array}{r}14 \mathrm{I} \\
285 \\
49\end{array}$ & $\begin{array}{l}- \\
-\end{array}$ & $\begin{array}{r}2 \\
-7\end{array}$ & $\overline{-}$ & $\begin{array}{r}8 \\
\mathrm{r}_{5} \\
2\end{array}$ & - & - & $\begin{array}{r}10 \\
40 \\
9\end{array}$ & $\begin{array}{r}91 \\
189 \\
19\end{array}$ & $\begin{array}{r}2 \\
83 \\
10\end{array}$ & $\begin{array}{r}4 \\
105 \\
19\end{array}$ & $\begin{array}{r}320 \\
\text { I076 } \\
\text { I I I }\end{array}$ \\
\hline 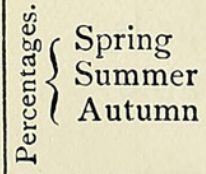 & $\begin{array}{l}\text { I. } 38 \\
1 \cdot 6 I \\
2 \cdot 70\end{array}$ & $\begin{array}{l}44 \cdot 06 \\
26 \cdot 49 \\
44 \cdot 14\end{array}$ & $\begin{array}{l}- \\
1.86 \\
-\end{array}$ & $\begin{array}{l}.62 \\
.65 \\
-\end{array}$ & $\stackrel{-}{-39}$ & $\begin{array}{r}2.50 \\
\mathrm{I} 4.13 \\
1.81\end{array}$ & $\overline{74}$ &. & $\begin{array}{l}3.13 \\
3 \cdot 7 \mathrm{I} \\
8.11\end{array}$ & $\begin{array}{l}28 \cdot 44 \\
17 \cdot 56 \\
17 \cdot 12\end{array}$ & $\begin{array}{r}.62 \\
7 \cdot 71 \\
9 \cdot 01\end{array}$ & $\begin{array}{r}1 \cdot 25 \\
9 \cdot 76 \\
17 \cdot 12\end{array}$ & $\bar{z}$ \\
\hline
\end{tabular}


As the flowers of the classes under consideration set themselves apart almost completely for the larger Apidae, we give here the seasonal distribution of these bees :-

TABLE XXX.

Seasonal distribution of Bees. The sequence is the sequence of their tongue-lengths.

\begin{tabular}{|c|c|c|c|c|}
\hline Name. & Spring (23 days). & Summer (88). & Autumn (x2). & Total. \\
\hline Bombus hortorum & 3 & I 2 & - & I 5 \\
\hline B. agrorum . & 5 & 49 & 44 & 98 \\
\hline B. venustus. . & - & 9 & - & 9 \\
\hline B. smithianus . & - & - & 1 & I \\
\hline B. cognatus - . & - & - & 2 & 2 \\
\hline B. lapidarius & 3 & - & 3 & 6 \\
\hline $\begin{array}{l}\text { B. lapponicus, with } \\
\text { B. pratorum }\end{array}$ & & & & \\
\hline B. jonellus, and & I82 & 163 & I I & $35^{6}$ \\
\hline $\begin{array}{l}\text { B. scrimshiranus } \\
\text { Psithyrus quadricolor }\end{array}$ & - & I0 & I & II \\
\hline Bombus terrestris. & 77 & 76 & 240 & 393 \\
\hline Bombi (unidentified) & 2 & 43 & I & $4^{6}$ \\
\hline Apis mellifica . & 160 & 266 & 4 & $43^{\circ}$ \\
\hline Total . . & $43^{2}$ & 628 & 307 & 1367 \\
\hline
\end{tabular}

We may class these bees by their tongue-lengths: Bombus hortorum to B. cognatus first, B. lapidarius and B. lapponicus second, Psithyrus quadricolor and Bombus terrestris third, and Apis last.

TABLE XXXI.

Bees in season by their tongue-lengths.

\begin{tabular}{|c|c|c|c|c|c|c|}
\hline & \multicolumn{2}{|r|}{ Spring. } & \multicolumn{2}{|c|}{ Surmmer. } & \multicolumn{2}{|c|}{ Autumn. } \\
\hline & No. & $\begin{array}{l}\text { Percentage } \\
\text { of total } \\
\text { insects. }\end{array}$ & No. & $\begin{array}{l}\text { Percentage } \\
\text { of total } \\
\text { insects. }\end{array}$ & No. & $\begin{array}{l}\text { Percentage } \\
\text { of total } \\
\text { insects. }\end{array}$ \\
\hline Tongue $15 \mathrm{~mm}$. and over & 8 & .19 & 70 & .72 & 47 & I.4I \\
\hline Tongue $10-15 \mathrm{~mm}$. long & 185 & $4 \cdot 4 \mathrm{I}$ & 163 & I. 67 & 14 & .42 \\
\hline Tongue 7 -10 $\mathrm{mm}$. long. & 77 & 1.83 & 86 & .88 & $24 \mathrm{I}$ & $7 \cdot 25$ \\
\hline Tongue $6 \mathrm{~mm}$. long . & 160 & $3.8 \mathrm{I}$ & 266 & $2 \cdot 7^{2}$ & 4 & .01 \\
\hline
\end{tabular}




\section{Willis and Burkill.-Flowers and Insects.}

It remains now to compare our results with those of other observers, and the table which follows does this. As in the case of $\mathrm{B}^{\prime}$ and $\mathrm{A}^{\prime}$, we again find Müller's observations very closely supported by those of Knuth, Verhoeff, Alfken and others on the coast of North Germany. Again we see the Alps showing an abundance of Lepidoptera, and our own country an abundance of short-tongued flies. Further comment is reserved.

TABLE XXXII.

Comparison of species-visits to Clova flowers of Classes $\mathrm{F}$ and $\mathrm{H}$ in various parts of Europe.

\begin{tabular}{|c|c|c|c|c|c|c|c|c|c|c|c|c|}
\hline & & & 常 & $\overline{\mathbf{I}}$ & 至 & 党 & $\stackrel{9}{9}$ & คี & $\stackrel{\infty}{A}$ & ن & 童 & 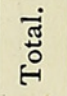 \\
\hline Clo & $(57 \mathrm{p}$ & lants) & I7 & 85 & 3 & 14 & 56 & 36 & 95 & I9 & I 2 & \\
\hline Germany $-\mathrm{N}$ & (35 & , ) & 25 & 230 & 78 & 2 & 73 & 46 & I & I9 & 2 & 476 \\
\hline Flanders-MacLeod & $(25$ & $"$ ) & 10 & 74 & 15 & I0 & 46 & 12 & 7 & 8 & - & 182 \\
\hline $\begin{array}{l}\text { Friesian coast-Knuth, } \\
\text { Verhoeff, \&c. }\end{array}$ & '(37 & , & 23 & 293 & 66 & 8 & 54 & $3^{2}$ & I 2 & 6 & I & 495 \\
\hline Alps & $(23$ & $\Rightarrow \quad$ ) & 3 & 90 & 2 & I & 179 & I0 & I & 6 & 2 & 294 \\
\hline Pyrenees-MacLeod. & (II & ”. & - & $4 \mathrm{I}$ & 2 & - & $2 \mathrm{I}$ & 9 & I & I & - & 75 \\
\hline
\end{tabular}

In conclusion, Classes $\mathrm{F}$ and $\mathrm{B}$ obtained the visits of Apis mellifica, of nine species of Bombi (all in the district except B. cognatus and B. scrimshiranus), of Psithyrus quadricolor, of two species of Andrena, of a Nomada, and two species of Odynerus, of two species of Vespa, of two kinds of ants, and of two species of ichneumons, of eight butterflies, of twelve of the Noctuid moths which are almost entirely crepuscular or nocturnal, of five geometers, of five ordinary Micro-lepidoptera, including Hepialis humuli, and also of Eriocephala calthella; among Diptera, of thirteen Syrphidae including Rhingia campestris, of five species of Empis, of one Rhamphomyia, of four Muscids, of one Sarcophaga, and of Siphona geniculata, of eight Anthomyiids including Drymia hamata, of two Scatophagids, and of eleven other flies; of six Coleoptera, of two Hemiptera, of Thrips and of a spider.

Thus Iog species of insects visited the two classes, making $I, 507$ individual visits, the average constancy being 13.83 . 


\section{$2 \mathrm{BHL}$ Biodiversity Heritage Library}

Willis, J. C. and Burkill. I. H. 1903. "Flowers and insects in Great Britain. part III. Observations on the most specialized flowers of the Clova mountains." Annals of botany 17, 539-570. https://doi.org/10.1093/oxfordjournals.aob.a088931.

View This Item Online: https://www.biodiversitylibrary.org/item/235015

DOI: https://doi.org/10.1093/oxfordjournals.aob.a088931

Permalink: https://www.biodiversitylibrary.org/partpdf/318729

\section{Holding Institution}

Smithsonian Libraries

\section{Sponsored by}

Biodiversity Heritage Library

\section{Copyright \& Reuse}

Copyright Status: Not in copyright. The BHL knows of no copyright restrictions on this item.

This document was created from content at the Biodiversity Heritage Library, the world's largest open access digital library for biodiversity literature and archives. Visit BHL at https://www.biodiversitylibrary.org. 